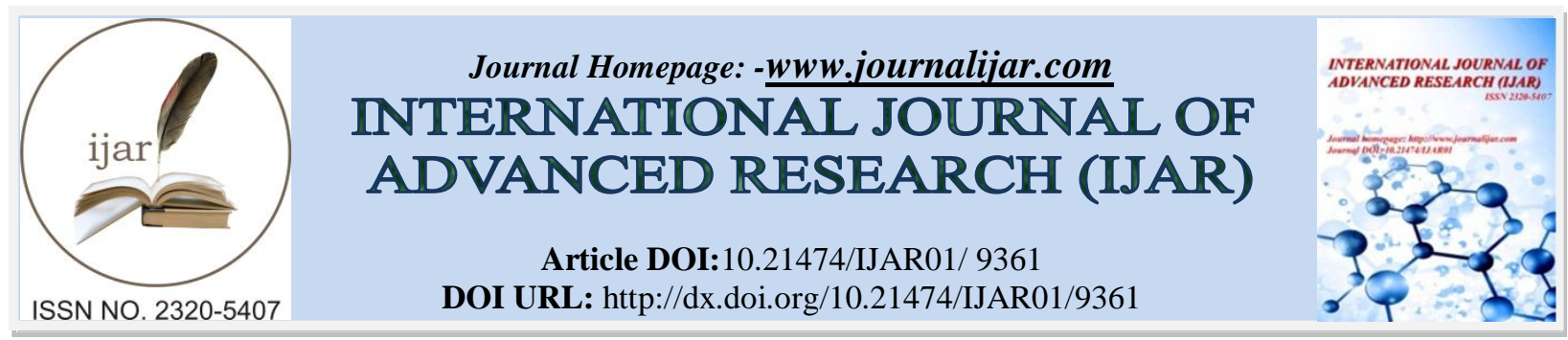

RESEARCH ARTICLE

\title{
JYOTISHMATI: AN ARTAVAPRAVARTAKA.
}

Dr. Keerti Yadav ${ }^{1}$, Dr.Vidya Ballal ${ }^{2}$ and Mr. Ravi Mundugaru ${ }^{3}$.

1. Assistant Professor M.S. (Ayu), Dept. of Prasooti Tantra and Stree Roga, Major S. D. Singh P. G. Ayurvedic Medical College and Hospital Fatehgarh- Farrukhabad, U. P.

2. Associated Professor, dept. of PG studies in Prasooti tantra and Stree roga SDMCA Udupi. Karnataka.

3. Research Officer, Dept. Of Pharmacology S. D. M. Research Centre, Udupi, Karnataka.

\section{Manuscript Info}

\section{Manuscript History}

Received: 06 May 2019

Final Accepted: 08 June 2019

Published: July 2019

Key words:-

Artava, Artavapravartaka, Jyotishmati, Celastrus paniculatus.

\begin{abstract}
Jyotishmati (celastrus paniculatus) has been used in the Indian system of medicine since long time. In Vedic kala and Upnishad jyotishmati is mentioned as a medhya. Acharya Charaka, Sushruta and Vagbhatta mentioned as a sirovirechana. In Bhava prakasha the properties of Jyotishmati plant explained as a kaphahara, tikshana and vamaka ${ }^{1}$. Adarsh nighantu classified the jyotishmati plant under taila varga, ashta varga and arka varga. In Ayurveda classics Jyotishmati plant explained as an artavapravartaka. In Bhaisajya Ratnavali acharya has mentioned that jyotishmati patra rosted with ghrita and ground with durva swarasa act as an artava pravartaka ${ }^{2}$. Jyotishmati pushpa, sajji kshara, vacha and asana kashtha churna with sheetal jala is artava pravartaka. Jyotishmati moola is one of the ingredients of shishukalpadruma ghrita which is used for anartava, kashtartava, yoni roga and vandhya.
\end{abstract}

Copy Right, IJAR, 2019,. All rights reserved.

\section{Introduction:-}

Jyotishmati (celastrus paniculatus wild.) mentioned in Ayurveda as 'Tree of life', a plant belonging to family Celastraceae was in use from time immemorial to treat brain related disorders and to enhance learning and memory. The jyotishmati oil extracted from the seeds of C. paniculatus is known to have effect on central nervous system. C. paniculatus shows many activities along with main activity i.e. memory enhancing effect. Its reported activities are antiviral, antibacterial, insecticidal, emmenagogue, anti inflammatory, antispermtogenic, sedative, anti fungal, analgesic and hypolipidemic. It is arthralgenic, antirhumatic, aphrodisiac, emetic, laxative nervine tonic. Plant is widely used for its medicinal properties ${ }^{3}$.

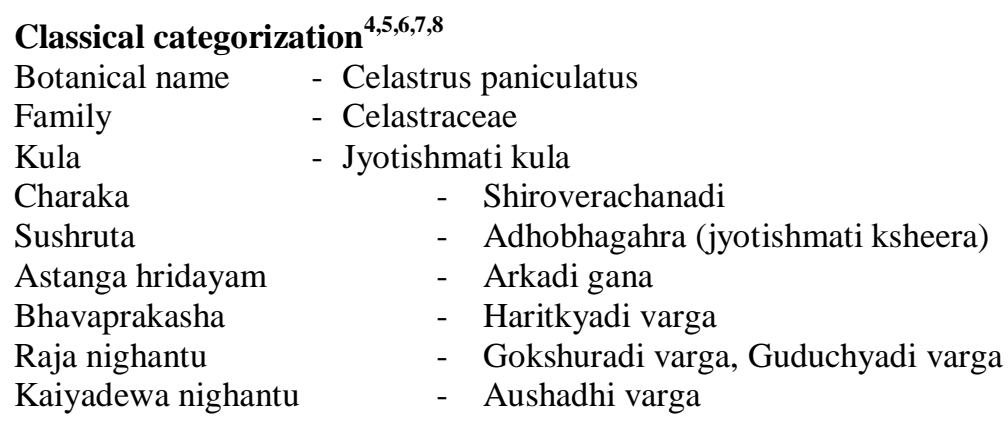


$\begin{array}{ll}\text { Dhanvantari nighantu } & - \text { Guduchyadi varga } \\ \text { Nighantu adarsha } & - \text { Jyotishmatyadi, Arka varga, Ashta varga } \\ \text { Priya nighantu } & - \text { Pippalyadi varga }\end{array}$

Vernacular names

Hindi : Malkangani

English : Staff tree

Kannada : Kariganne

Malyalam : Paluruvam

Tamil : Valulavai

Synonyms - Tejasvini, Katabhi, Pita Taila, Supingala, Kakandi, Paravatpadi, Vega, Katvika, Kangunika

$\begin{array}{ll}\text { Rasapanchaka } & \\ \text { Rasa } & - \text { Katu, Tikta } \\ \text { Guna } & - \text { Teekshna, Snigdha, Sara } \\ \text { Virya } & - \text { Ushna } \\ \text { Vipaka } & - \text { Katu } \\ \text { Prabhava } & - \text { Medhya } \\ \text { Doshagnata } & - \text { Kapha-Vatahara }\end{array}$

Karma-

Deepana, Pachana, Artavajanana, Vedanasthapana, Medhya, Vatahara, Uttejaka, Nadibalya, Mastishkashamaka, Vatanulomana, Hridyotttejaka, Shothahara, Shirovirechana, Kaphaghna, Vrikkittejaka, Mootrala, Vajikarana, Kushthaghna, Swedajanana, Amapachana, Jwaraghna.

\section{Rogaghnata-}

Kaphavatajavikara, Kushta, Udara, Gulma, Vatavikara, Pakshaghata, Ardita, Sandhivata, Gridhrasi, Katishoola, Dhwajabhanga, Gandamala, Mastishkaroga, Nadidaurbalya, Agnimandhya, Vibandha, Gulma, Haridayamandata, Shotha, Kasa, Shwasa, Sheetadhikyajanya, Mootrakrichahhra, Kashtartava, Klaibya, Kandu, Jwara.

\section{Prayojyanga-}

Seeds, Root, Root Bark, Leaves, Bark

\section{Matra}

Beeja 1-2gm

Taila 5-15drops

\section{Action and uses}

1. Bark- Abortifacient, Depurative and Brain Tonic.

2. Leaves- Emmenagogue, leave juice- used in dysentery, a good antidote for opium poisoning.

3. Seeds- Acrid, bitter, laxative, thermogenic, emollient, rubefacient, stimulant, intellect promoting, digestive, emetic, expectorant, appestiser, aphrodisiac, cardiotonic, anti inflammatory, diuretic, emmenagogue, diaphoretic, febrifuge and tonic.

4. Abdominal disorders, depression, arthritis, asthma, cardiac debility, inflammation, strangury, nephropathy, amenorrhoea, dysmenorrhoea and fever. They are reported to sharpen the memory.

5. Seed oil- Bitter, thermogenic, intellect promoting, abdominal disorder, beri-beri, rheumatic pain, sores, wound, and eczema.

6. Root- crushed root is used for pneumonia.

\section{Phytoconstituents}

The leaves contain alkaloids, saponin, a glycoside and coloring matter. The leaves are emmenagogue and leaf sap is a good antidote for opium poisoning. It acts as antimicrobial and antifungal. Preliminary phytochemical screening of the petroleum ether and ethyl acetate extracts of leaves reveals the presence of steroid and terpenoid while methanol extracts show positive results for steroid, terpentoid, carbohydrate, alkaloid, saponin and phenolic compounds.

Root bark and stem- Pristemerin 
Seed - Celapagine, Celastrine, Paniculatine, Malkanguniol, Malkangunin, Paniculatadiol, $\beta$ Sitosterol, $\beta$ Amyrin, Acetic Acid, Benzoic Acid, Formic Acid, Linoleic Acids, palmitic and stearic acids, celapanigine, celapanine, celastrol, 5-stigmasten-3 $\beta$-ol.

Seed oil- malkanguni oil, malkanguniol, sesquiterpene ester-malkangunin, two sesquiterpenoid tetra esterscelapanine and celapanigine, triterpene diol, paniculatadiol, $\beta$ amyrin, $\beta$-sitosteriol and fatty acids.

Whole plant- Dishydroagarofuran sesquiterpene polyesters.

\section{Pharmacological activities-}

Antihistaminic, sedative, anticonvulsant, antiprotozoal, antiviral, antipyrectic, antiulcerogenic, anti-emetic, antibacterial, schizontocidal, emmenagogue, hypotension, stimulant, central muscle relaxant, hypolipidaemic, antiatherosclerotic, spasmolytic, tranquillier, anti inflammatory, antifertility (antispermatogenic).

\section{Mode of action of Jyotishmati as Artavapravartaka}

Jyotishmati plant is having katu, tikta rasa, teekshana guna, ushna veerya and katu vipaka helps in vilyana of kapha and alleviating the vata dosha relieving the obstruction, it also helps in agnivardhana, amapachana so there will be proper formation of rasadi dhatu. Artava is the upadhatu of rasa dhatu so there will be proper formation of artava also.

\section{Snigdha guna:}

Snigdha guna having lepana shakti, kledana and vatahara properties helps in regeneration of endometrium layer and strengthens apana vata function.

\section{Sara guna:}

Jyotishmati plant is having the sara guna. According to acharya's the properties of sara guna are-

xÉUxiÉåwÉÉÇ mÉëuÉ" ÉïMü:|(B. P. Pu. Mi. 6/204)

xÉUÉåÅlÉÑséÉåqÉlÉ: mÉëÉåđü:|(Su. S. Su. 46/522)

Sara guna is having the property of anulomana and pravartaka so, it helps in the vatanulomana and pravrtaka of artava. It also acts as vedanasthapana and helps in relieving pain caused by vitiated vata which causes pain during menstruation.

Sara guna is also acts as lekhana so it will help in the proper shedding of the endometrium.

\section{Teekshana guna:}

According to astanga hrudaya teekshana guna is having the shodhana property which helps in sroto shodana probably removes obstruction and srotorodha.

According to acharya sushruta, teekshna guna is having the properties of paka kara and stravan, paka helps in the proper formation of artava which competes with proliferation of the endometrium and stravan will help in the proper shedding of the endometrium. Ultimately there will be proper formation of the artava and artava srava which by itself is the line of treatment for anartava.

According to bhava prakasa, teekshna guna is having the properties of pittakara, lekhana and kaphavatahara. acharyas have mentioned pitta vardhaka and kapha vatahara chikitsa in anartava and artava kshaya so, jyotishmati drug helps in the samprapthi ghataka of anartava as it removes margavrodha by the shodana property and kapha vatahara property, helps the proper formation of artava with the pittakara property, and helps in the proper sravan by its lekhana property and thus does the upashaya of the disease proper by kaphavatahara properties.

\section{Katu rasa:}

Jyotishmati plant is having katu rasa and the properties of katu rasa according to Acharya Charaka is 'sonitasamghatam bhinathi' that breaks down the accumulated blood and 'margan vivrnoti' clears and dilates the passages and alleviates kapha. So, in anartava like conditions jyotishmati helps by the removing the obstruction and cleanses the accumulation of the blood. According to acharya Vagabhata, katu rasa is having lekhana property thus proper shedding of the endometrium is an added benefit. 
According to acharya Charaka and Vagbhatta katu rasa is having the properties of deepana and pachana so it will help in the proper formation of rasadi dhatu and proper formation of artava also.

\section{The action of katu rasa on dosha -}

it increases the pitta, which supports the principles of treatment of anartava.

\section{Tikta rasa:}

1. Jyotishmati plant is having tikta rasa, in ayurveda, tikta rasa is having the properties like bhaktaruchi (appetizer) and mamsa vardhaka and in modern science also principles of bitter substances is excellent stomachics and augment the capacity of muscular work. So this can be helpful in the condition like amenorrhoea due to anorexia nervosa or weight loss because for regular menses are unlikely to occur in those with BMI below $19 \mathrm{~kg} / \mathrm{m}^{2}$.

2. Tikta rasa is having lekhana property also it will help in the proper shedding of the endometrium.

\section{Ushna veerya:}

Jyotishmati is having usna veerya. Usna veerya pacifies kapha and vata, aggravates pitta, which is the need for the chikitsa of anartava.

\section{Conclusion:-}

On the observation of ayurvedic literature and the rasa, guna, veerya and vipaka it seems that jyotishmati plant is having artavapravartaka property and having a great role on the female reproductive system.

\section{References:-}

1. Prof. D. S. Lucas, Dravya guna - vijnananstudy of Dravya-Materia Medica Volume-2 ${ }^{\text {nd }}$, reprint year 2012, chaukhambha Bharati Academy, page no- 83, Pp- 911.

2. Siddhiprata Hindi Commentry By Prof. Siddhi Nandan Mishra, Bhaisajya Ratnavali of Kaviraj Govind Das Sen, reprint 2009, chaukhambha surbharti prakashan, Varanasi, page no 1044,Pp-1196.

3. Kamalinee A. Deodhar and nandamW. Shinde. Celastrus Paniculatus,; medicinal and pharmacological properties: A review, International journal of development research vol.5 issue 09,Page no.- 5527 pp. 5526-5531, September, 2015.

4. Available online at http://www.journalijdr.com

5. Lucas D. S., Dravya guna - vijnanan study of Dravya-Materia Medica Volume-2 ${ }^{\text {nd, }}$ reprint year 2012, Varanasi, chaukhambha Bharati Academy, Pp- 911 P-83.

6. Vaidya G Bapala, Nighantu Aadarsha, Reprint 2007, Vol-1 Pp-919, P-286

7. Sastry J. L. N., Dravyaguna Vijnana study of the essential plants in Ayurveda Vol. II, Varanasi, Chaukhamba Orientalia, Pp1118, P-128.

8. Sharma P. V, Dravyaguna -Vijnana Vol II (vegetable drugs), Reprinted 2013, Varanasi, Chaukhamba Bharathi Academy, Pp- 873, P- 11

9. Database on medicinal plants used in ayurveda, volume 2, P.C. Sharma, M.B. yelne T. J. Dennis, Chaukhambha publications, new Delhi, reprinting 2005, Pp-590,P- 282-283. 